\title{
Het portfolio levert geen wezenlijke bijdrage aan de kwaliteit van de specialistenopleiding ${ }^{1}$
}

\author{
M. Vermeulen
}

Tegen een eenvoudig portfolio kan geen bezwaar bestaan. Een dergelijk portfolio in de specialistenopleiding bevat dan een opsomming van de stages die gevolgd zijn in kliniek of polikliniek. Maar anders wordt het als het portfolio zodanig moet zijn samengesteld dat het de ontwikkeling van de arts in opleiding tot assistent (AIOS) weergeeft. De AIOS legt in dat geval zijn of haar vorderingen vast en reflecteert daarop, bij voorkeur in overleg met de opleider. Van de AIOS wordt verwacht dat hij daardoor inzicht krijgt in kennen en kunnen, meestal "competenties" genoemd. De AIOS beschrijft niet alleen de kennis en vaardigheden op medisch gebied, maar ook de interactie met patiënten, collega's, supervisors en verpleging. Door het reflecteren over verbeteringen in de toekomst krijgt het portfolio ook een prospectief karakter.1 Omdat dit type portfolio schriftelijk moet worden vastgelegd, meestal op uniforme wijze, kan een grote papierwinkel ontstaan. De vraag is of de opleiding hierdoor verbetert.

Interessant was de reactie van medewerkers van onderwijsinstituten van 2 verschillende umc's op mijn vraag of zij onderzoeken kenden die aantoonden dat portfolio's de opleiding verbeterden. Een medewerker benadrukte dat als ik over portfolio's wilde gaan schrijven, ik dat niet mocht zonder toestemming van de afdeling Onderwijskunde. Een medewerker van een ander instituut wilde weten waarom ik naar onderzoek vroeg en vervolgens hoorde ik niets meer. Een colleganeuroloog die de specialistenopleiding een warm hart toedraagt, leverde mij onderzoeken, niet over het portfolio

M. Vermeulen $(\bowtie)$

Prof. dr. M. Vermeulen is neuroloog.Correspondentieadres:

Prof. dr. M. Vermeulen, Academisch Medisch Centrum/

Universiteit van Amsterdam, afd. Neurologie, Postbus 22.660,

1100 DD Amsterdam. maar over postpolio(syndroom). Hij kwam niet op het idee dat ik het over het portfolio zou kunnen hebben, en ook specialisten en assistent-geneeskundigen die over de opleiding nadachten, brachten nergens het portfolio ter sprake. 2

Wij kennen het portfolio uit de kunst- en reclamewereld, maar vervolgens is het ook in de onderwijskunde omarmd. De literatuur die ik vond, stond in tijdschriften die ik nog nooit had gezien en bestond uit slecht geschreven stukken over slecht opgezette onderzoeken, die geen conclusie toelieten.

Het portfolio blijkt een belangrijk instrument te zijn in wat genoemd wordt het "nieuwe leren". Dit nieuwe leren berust op de principes van het sociaal constructivisme, waarvan de essentie is dat er geen objectieve werkelijkheid bestaat die gekend kan worden. Leerlingen construeren kennis door het geven van betekenis aan ervaringen met de wereld om hen heen. Daarop komt vanuit de onderwijskunde kritiek: zo concludeert Van der Werf dat er onvoldoende empirische steun is voor het nieuwe leren - eerder vindt zij steun voor het tegendeel. 3

Niets wijst op een gunstig effect van het portfolio op de opleiding en vanuit de onderwijskunde worden grote vraagtekens gezet bij het nieuwe leren, waarvan het portfolio een belangrijk onderdeel is, dat de toets vervangt. Daarom dient het portfolio in de specialistenopleiding onmiddellijk te worden afgeschaft.

Drs. Y.M. van der Brug, verplegingswetenschapper, van de Stafgroep Patiëntenzorg van het Academisch Medisch Centrum/Universiteit van Amsterdam, droeg relevante literatuur aan.

\footnotetext{
${ }^{1}$ Dit artikel verschijnt ook in het Nederlands Tijdschrift voor Geneeskunde.
} 


\section{Literatuur}

Belangenconflict: geen gemeld.

Financiële ondersteuning: geen gemeld.

\section{Literatuur}

McMullan M, Endacott R, Gray MA, Jasper M, Miller CML, Scholes J, et al. Portfolios and assessment of competence: a review of the literature. J Adv Nurs 2003;41:283-94.
Hoekstra JBL, Holleman F. De ideale opleider. Een enquête in de interne geneeskunde. Tijdschrift voor Medisch Onderwijs 2006;25:83-7.

Werf MPC van der. Leren in het studiehuis. Consumeren, construeren of engageren? [inaugurele rede]. Groningen: Rijksuniversiteit Groningen; 11 januari 2005. 